\title{
任意の多面体間に適用可能な干渉回避運動生成法
}

\author{
金 広 文 男*1 吉 田 英 一*1 Lamiraux Florent*2 \\ Kanoun Oussama*2 and Laumond Jean-Paul*2
}

\section{A Local Collision Avoidance Method for Non-strictly Convex Objects}

\author{
Fumio Kanehiro*1, Eiichi Yoshida*1, Florent Lamiraux*2, \\ Oussama Kanoun*2 and Jean-Paul Laumond ${ }^{* 2}$
}

\begin{abstract}
This paper proposes a local method to avoid collisions with continuous velocities. The main contribution of the method is that non-strictly convex polyhedra can be used as geometric models of the robot and the environment without any approximation. The problem of the continuous interaction generation between polyhedra is reduced to the continuous constraints generation between polygonal faces and the continuity of those constraints are managed by the combinatorics based on Voronoi regions of a face. A collision-free motion is obtained by solving an optimization problem defined by an objective function which describes a task and linear inequality constraints which do geometrical constraints to avoid collisions. The proposed method is examined using example cases of simple objects and also applied to a humanoid robot HRP-2.
\end{abstract}

Key Words: Collision Avoidance, Motion Planning, Distance Computation, Voronoi Region, QP Problem, Optimization, Humanoid

\section{1. 緒言}

我々の日常生活環境において活動するロボットにとって，環 境や自己との干渉を検知 (予測) し回避する能力は安全性の観 点から非常に重要な基本機能である。この機能に関する研究は 1980 年代から主にマニピュレータを対象として行われてきた が, 近年のヒューマノイド研究の広がりとともに再び重要な問 題となっている. これはヒューマノイドの機構が木構造となっ ている上に, それぞれの関節が広い可動範囲をもつために自己 干渉が起きやすく，ロボットが活動する環境もロボット用に整 備されていない様々な障害物が存在する環境が想定されるため である。

Fig. 1 に示すような「テーブルの下の物を拾い上げる」といっ た単純な動作でもロボットはテーブルとの干渉と脚を大きく折 り曲げることによる自己干渉を回避しながらタスクを遂行しな ければならない.

干渉回避運動の生成法は大きく二つに分類することができる. 一つ目の生成法は，まず干渉の有無を考慮に入れずにタスク

原稿受付 2008 年 1 月 16 日

*1 産業技術総合研究所

${ }^{* 2}$ LAAS-CNRS, University of Toulouse

${ }^{* 1}$ National Institute of Advanced Industrial Science and Technology (AIST)

${ }^{* 2}$ Laboratoire d'Analyse et d'Architecture des Systèms (LAASCNRS)

口本論文は学術性で評価されました。

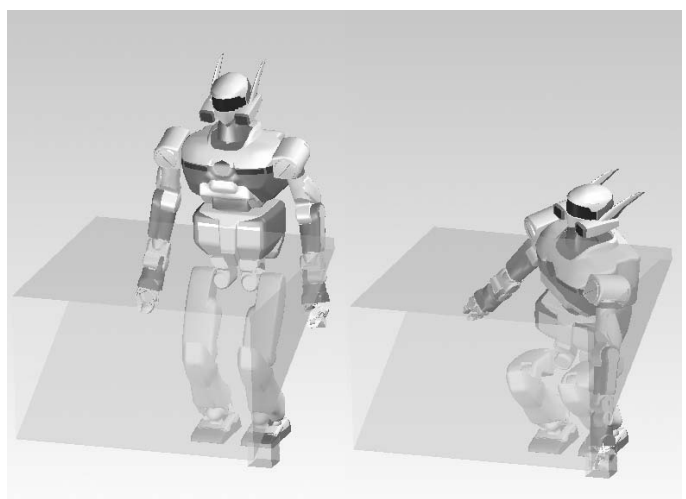

Fig. 1 "Pick up an object under the table" example

を達成するための運動を生成し，その後で干渉の有無を検査し て干渉が予測される場合にはその運動を停止する, あるいは再 度運動生成を行う，というものである。文献 [1] はあらかじめ 作成しておいた多数の静的に安定な姿勢の集合に対して RRTconnect [2] を適用して経路を計画し，これを動力学フィルタ [3] に通すことによって動的に安定な軌道へと変換する手法を提案 している. 文献 [4] は歩行動作における自己干渉の有無をオンラ インで検査し，干渉が予測される場合にはその動作を捨ててあ らかじめ干渉がないことを確認済みの動作に切り替えることで 安定に動作を停止する方法を提案している。この方法はロボッ トの各リンクの形状を凸包によって近似し, それらの間の最短距 離を V-Clip [5] を用いて追跡することで非常に高速な検査を実 
現している. 文献 [6] はオンラインで自己干渉検査を行うために 三つの手法を組み合わせ，干渉が予測される場合にはそこで動 作を停止する方法を提案している. 三つの手法とは（1）隣接す るリンク間の自己干渉のテーブルルックアップによる検出，（2） 干渉チエックを行うリンクのペア数の構造に関する知識を用いた 削減，(3）凸包によって近似されたリンク間の干渉検査，である。

このような干渉回避運動の生成法は, 干渉回避を考慮してい ない既存のシステムを安全に運用できるように拡張するような 用途には有用であるが, 最初に干渉を考慮せずに運動生成を行 うために, 多くの運動候補の生成が必要とされることが予想さ れる。このことは自由度数が大きいヒューマノイドのようなシ ステムにとって深刻な問題である。このことから筆者らは二っ 目の生成法である, 干渉回避を夕スクを達成するための運動生 成に扔ける拘束条件として適用し, 運動生成と干渉回避を同時 に行う生成法を選択した。

このような手法で最も著名で広く用いられているのが Faverjon らが提案した方法 [7] であろう. Faverjon らは干渉回避運 動生成をタスクを達成するための目標速度と実際に行う運動の 速度の差を干渉を回避するための不等式拘束条件下で最小化す る問題として取り扱っている. 干渉回避のための拘束条件は物 体間の最近点と最短距離に基づいて生成されており, 同様の手 法は以下のような数多くの研究で用いられている. 文献 $[8]$ は 文献 [7]のタスクの記述方法を変更することで, 複雑な環境下 においてローカルミニマムを避けることができるように文献 [7] の手法を拡張した，文献 [9] はロボットの形状を楕円体を用い て近似し, 物体間の距離の勾配を用いて干渉を回避する方法を 提案した．文献 [10] は物体間の最短距離に基づくポテンシャル フィールドを生成し, 干渉回避を行っている. 文献[11] は球と 円筒の集合によって形状を近似し, その近似形状外縁に近似形 状までの距離に応じて仮想的な反発力を発生させるフィールド を持った形状表現を RoBE と呼び，これを自己干渉回避に用い ている. 文献 [12] も同様に球とその掃引体によって形状を近似 し，それらの間の最短距離を自己干渉の回避に用いている.

物体間の最近点と距離の情報に基づいて運動生成を行う場合, 連続な速度による運動を解として得るには, 物体の形状は狭義 に凸でなければならないという制約がある。これは狭義に凸な 形状間の距離は, 物体間の相対運動空間 $S E(3)$ から $\mathbb{R}^{+}$への連 続的微分可能なマッピングであるのに対して, 物体形状が狭義に 凸でない場合には，連続であるが微分不可能であるためである。

一方で多くの場合，ロボットの形状データは CAD モデル等 を元に生成された多面体として与えられる，任意の多面体間の 距離を求めるアルゴリズムの研究やそのロバストな実装はすで に存在する [13] [14] ものの, 多面体間の距離に基づく拘束を運 動生成に使用すると多面体は狭義に凸な形状ではないために得 られる速度が不連続になってしまう。そのため多くの研究が形 状を狭義に凸な球や楕円体で近似している，元の形状を精度よ く近似するためには球等を多数使用することが必要となるため, 少数の物体で, より精度高く物体形状を近似するための方法も 研究されている. 文献 [15] は STP-BV と呼ぶ球とトーラスの 張り合わせからなる形状を用いることで非常に高い精度で物体 形状を狭義に凸な形状で近似することを可能としている.
このように物体形状を狭義に凸な形状で近似することで連続 な速度による干渉回避運動生成を可能とするための研究は数多 く行われているが, 一方で任意の多面体形状を取り扱える運動 生成法の研究はほぼ皆無である. しかし運動生成手法が任意の 多面体に適用可能なものとなれば，与えられた多面体をさらに 近似することなく使用することが可能となり, 多面体を狭義に 凸な形状の集合で近似するという手順が不要になる。

本稿では Faverjon らが提案した方法を元に, 形状が任意の 多面体として与えられた場合でも連続な速度による干渉回避運 動を生成する手法を提案する.

ロボットの目標速度を近接した物体によって生成される不等 式拘束を満たす部分空間に投影することにより，干渉を回避し ながら夕スクを達成するための速度を求める, という枠組みは Faverjon らの方法と同じであるが, Faverjon らの方法では近 接した物体間には一つの拘束が生成されるのに対して, 本手法 では形状に応じて複数の拘束が生成される点が異なる.

提案する手法は, 多面体間の連続な速度による干渉回避の問 題を多面体を構成する三角形間の干渉回避問題に帰着させ, 一 方の三角形を構成する辺ともう一方の三角形のボロノイ領域と の位置関係の組み合わせに基づいてそれらの三角形の間に連続 な拘束を発生させる, というものである.

本稿は以下のように構成されている，2 章では文献 [7] で提案 されている狭義に凸な形状に対する手法を解説する．３章では この方法を任意の多面体が扱えるように拡張する，4 章では提 案した手法を最初に単純な形状の物体同士の例を用いて, 次に 複雑な機構をもつヒューマノイド HRP-2 [16] の例を用いて検 証する， 5 章で本論文をまとめ, 今後の課題について述べる.

\section{2. 狭義に凸な形状間の干渉回避法}

\section{1 狭義に凸な物体形状}

最初に「狭義に凸」の定義を確認しておく. 定義は以下のと おりである。

Definition: 狭義に凸. $\mathcal{O} を \mathbb{R}^{3}$ の部分閉空間, $\operatorname{int}(\mathcal{O})$ を $\mathcal{O}$

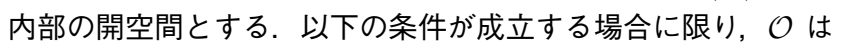
狭義に凸であるという。

$\forall A \in \mathcal{O}, \forall B \in \mathcal{O}, \forall \lambda \in \mathbb{R}, 0<\lambda<1, \lambda A+(1-\lambda) B \in \operatorname{int}(\mathcal{O})$

例えば凸包はもはや狭義に凸な形状ではない，その一つの面上 の 2 点を $A, B$ として選択した場合, それらを結ぶ線分は, 多 面内の内側ではなく表面上にあるからである.

\section{2 干渉回避方法}

本節では Faverjon らが提案した手法を概説する. $\mathcal{O}_{1}$ と $\mathcal{O}_{2}$ をそれぞれ狭義に凸な物体であるとする。ここでは説明を簡単

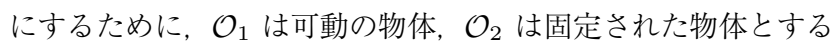
が, 双方が可動の物体の場合にも容易に拡張可能である。 また $\boldsymbol{p}_{1}$ と $\boldsymbol{p}_{2}$ を $\mathcal{O}_{1}$ と $\mathcal{O}_{2}$ の間の最近点とし, それらの間の距離 $\left\|\boldsymbol{p}_{1}-\boldsymbol{p}_{2}\right\|$ を $d$ と表す (Fig. 2 参照)。 $\mathcal{O}_{1}$ と $\mathcal{O}_{2}$ は狭義に凸な 物体であるため, $\boldsymbol{p}_{1}$ と $\boldsymbol{p}_{2}$ はそれらの表面上を連続に移動し, $d$ は連続的微分可能である。

$d$ が influence distance と呼ばれる距離の閾值（以下 $d_{i}$ と表 す）よりも小さくなると, 以下のような拘束条件が $d$ の速度 $\dot{d}$ 
に対して適用される。この物体表面からの距離が $d_{i}$ 以下であ る空間をinfluence zone と呼ぶ.

$$
\dot{d} \geq-\xi \frac{d-d_{s}}{d_{i}-d_{s}}
$$

不等式拘束（1）は velocity damper と呼ばれ， $d$ が $d_{i}$ よりも 小さくなるとその減少の度合を制限する， $\xi$ は収束の度合を調 整するための正の係数, $d_{s}\left(<d_{i}\right)$ は security distance と呼ば れる正の值であり， $d$ がこの值以下にならないように拘束され る.ここで $d$ が $d_{i}$ より小さくなる瞬間には $\dot{d}$ は不等式拘束 （1）を満たしていなければならないという点に注意が必要であ る.もし速度がこの拘束を満たしていなかった場合には，dは 不連続に変化してしまう。このため， $\xi$ の值はアプリケーショ ンに応じて調整しなればならない，

$\dot{d}$ は次式により求められる.

$$
\dot{d}=\left(\dot{\boldsymbol{p}}_{1} \mid \boldsymbol{n}\right)
$$

ここで $\boldsymbol{n}$ は単位べクトル $\left(\boldsymbol{p}_{1}-\boldsymbol{p}_{2}\right) / d$ であり, $(\boldsymbol{u} \mid \boldsymbol{v})$ はべク トル $\boldsymbol{u}$ と $\boldsymbol{v}$ の内積を表す.

$\boldsymbol{q}, \dot{\boldsymbol{q}}$ をそれぞれ $\mathcal{O}_{1}$ のコンフィギュレーション, 速度とする と, $\mathcal{O}_{1}$ の表面上の点である $\boldsymbol{p}_{1}$ の速度は以下のように表される。

$$
\dot{\boldsymbol{p}}_{1}=\boldsymbol{J}\left(\boldsymbol{q}, \boldsymbol{p}_{1}\right) \dot{\boldsymbol{q}}
$$

ここで $\boldsymbol{J}\left(\boldsymbol{q}, \boldsymbol{p}_{1}\right)$ は $\boldsymbol{p}_{1}$ における $\mathcal{O}_{1}$ のヤコビ行列である.

式 (2)，（3）を不等式拘束（1）に代入することにより，不等 式拘束（1）は以下のように $\mathcal{O}_{1}$ の速度 $\boldsymbol{q} に$ 対する線形不等式 拘束となる。

$$
\left(\dot{\boldsymbol{q}} \mid \boldsymbol{J}\left(\boldsymbol{q}, \boldsymbol{p}_{1}\right)^{T} \boldsymbol{n}\right) \geq-\xi \frac{d-d_{s}}{d_{i}-d_{s}}
$$

ロボットのタスクが作業空間におけるべクトル $\boldsymbol{\tau}(\boldsymbol{q})$ によっ て表され， $\boldsymbol{\tau}(\boldsymbol{q})=\mathbf{0}$ となるような $\boldsymbol{q}$ に到達することによって タスクが達成されるとする. タスクを達成するための作業空間 に扔ける目標速度主が与えられたときに，干渉を回避しつつ夕 スクを達成する速度 $\dot{\boldsymbol{q}}$ は以下のような $\dot{\boldsymbol{q}}$ に関する最適化問題 を解くことによって得られる。

$$
\min _{\dot{\boldsymbol{q}}} \quad\left\|\boldsymbol{J}_{\tau}(\boldsymbol{q}) \dot{\boldsymbol{q}}-\underline{\boldsymbol{\tau}}\right\|^{2}
$$

subject to $\left(\dot{\boldsymbol{q}} \mid \boldsymbol{J}\left(\boldsymbol{q}, \boldsymbol{p}_{1}\right)^{T} \boldsymbol{n}\right) \geq-\xi \frac{d-d_{s}}{d_{i}-d_{s}}$.

ここで $\boldsymbol{J}_{\tau}(\boldsymbol{q})$ は $\boldsymbol{\tau}(\boldsymbol{q})$ の $\boldsymbol{q}$ におけるヤコビ行列である.

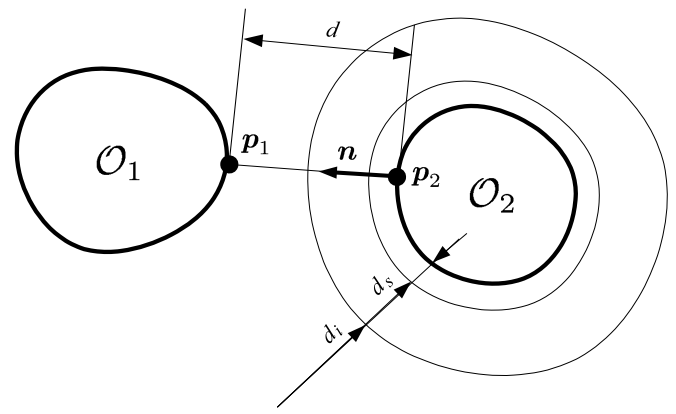

Fig. 2 Faverjon and Tournassoud's method
以上はロボットと環境がそれぞれ一つの物体で構成される場 合であるが， ロボットや環境が複数の物体から構成される場合 には，上記の不等式制約条件を物体の組み合わせごとに一つず つ適用する。

Property: もし $\dot{\boldsymbol{\tau}}$ がすべての時間において連続であり，条件 $\dot{d} \geq-\xi$ が $\boldsymbol{p}_{1}$ が influence zone に入る瞬間に満たされており, ロボットと環境の物体が狭義に凸な形状で与えられた場合には 最適化問題（4）は連続な速度を返す。

\section{$2.3 \mathcal{O}_{1}$ と $\mathcal{O}_{2}$ の間の最小距離}

$\mathcal{O}_{1}$ と $\mathcal{O}_{2}$ の間の時刻 $t$ に扔ける最短距離を $d(t)$ と表すと, $d(t)$ は連続的微分可能な関数である. $d(t)$ の微分 $\dot{d}(t)$ に関す る拘束条件,

$$
\forall t>0, \dot{d}(t) \geq-\xi \frac{d(t)-d_{s}}{d_{i}-d_{s}}
$$

と初期条件 $d(0) \geq d_{s}$ が成り立つとき, 以下の条件式が導か れる。

$$
\forall t>0, d(t) \geq d_{s}+\left(d(0)-d_{s}\right) e^{-\frac{\xi}{d_{i}-d_{s}} t}>d_{s}
$$

これは velocity damperによって拘束された物体間の距離は決 して $d_{s}$ 以下にはならないことを示している.

\section{3． 任意の多面体における干渉回避}

\section{1 狭義に凸でない物体において不連続速度が発生する例}

狭義に凸でない形状に対して Faverjon らの手法を適用した場 合, 二つの物体間の最近点が不連続に移動するために速度が不連 続になる現象が発生する. Fig. 3 と Fig. 4 にこのような現象が 発生する一例を示す。この例では長方形 $(0.2 \times 0.8[\mathrm{~m}])$ と床面 が存在し, 長方形のタスクはその中心点 $\boldsymbol{p}_{c}(\boldsymbol{q})$ を $(0.0,0.7)^{T}[\mathrm{~m}]$ から $\boldsymbol{p}_{g}=(0.0,-1.0)^{T}[\mathrm{~m}]$ へと移動させることである。velocity damper で用いられるパラメー夕， $d_{i} ， d_{s}, \xi$ はそれぞれ $0.4[\mathrm{~m}], 0.2[\mathrm{~m}], 0.5[\mathrm{~m} / \mathrm{s}]$ とし, $\dot{\underline{\tau}}$ は次式によって与えた.

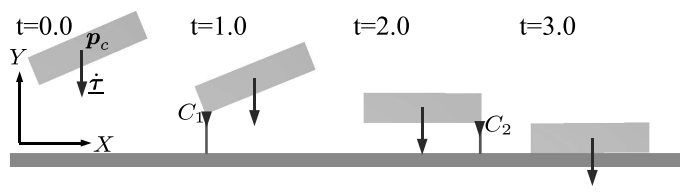

Fig. 3 Example of a discontinuous constraint
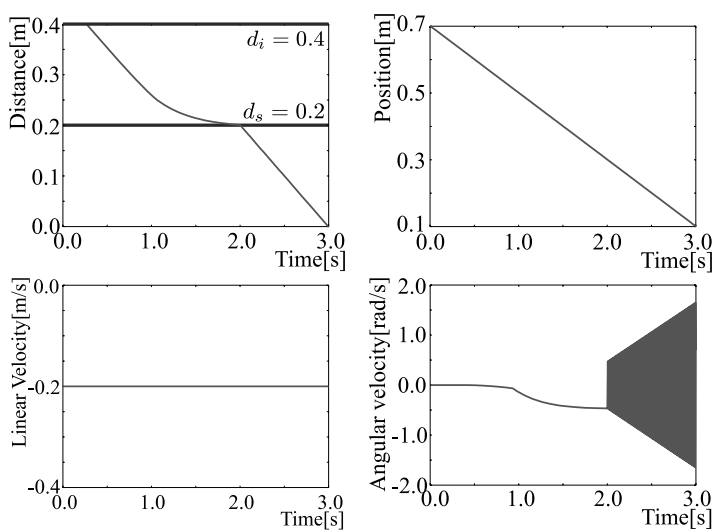

Fig. 4 Results of the example \#1 


$$
\underline{\dot{\tau}}(\boldsymbol{q})=-\delta \tau_{\max } \frac{\boldsymbol{p}_{g}-\boldsymbol{p}_{c}(\boldsymbol{q})}{\left\|\boldsymbol{p}_{g}-\boldsymbol{p}_{c}(\boldsymbol{q})\right\|}
$$

ここで $\delta \tau_{\max }$ は 0.2 とした.

Fig. 4 左上のグラフは長方形と床面の最短距離を, 右上は長 方形の $Y$ 軸方向の位置を, 左下は $Y$ 軸方向の並進速度を, 右 下は角速度を示している. 長方形左下の頂点 $C_{1}$ が $t=0.25$ 付近で influence zoneへ入る. しかしこの時点では $C_{1}$ の速度 は不等式拘束（1）によって計算される制限速度よりも大きいた め, 長方形の運動は影響を受けない. $t=0.5$ あたりから速度 は velocity damperによって制限される. 長方形の中心点は夕 スクを達成するために一定の速度で下方へ移動しなければなら ず， $C_{1}$ の下方への速度は制限を受けるため, 長方形は回転を始 める. $t=2.0$ あたりで長方形の長辺が床面に対してほぼ水平と なり, 最近点が $C_{1}$ と $C_{2}$ との間で発振し始める。これは, $C_{1}$ が拘束を受けているときは長方形は時計回りに回転してタスク を達成しようとし， $C_{2}$ が拘束を受けているときは反時計回り に回転してタスクを達成しようとするために発生する現象であ る. 結果として最短距離は $d_{s}$ を下回り, およそ $t=3.0$ では ついに床面と干渉してしまう.

このように物体形状が狭義に凸でない場合，前節で説明した 性質はもはや成立しない. 最近点が不連続に移動することによっ て最適化問題 (4) の $\boldsymbol{J}\left(\boldsymbol{q}, \boldsymbol{p}_{1}\right)$ や $\boldsymbol{n}$ が不連続に変化し, 結果 として最適化問題（4）の解である物体の速度 $\dot{\boldsymbol{q}}$ も Fig. 4 にあ るように不連続となってしまう。

\section{2 多面体間の運動の分解}

本節の目標は $\dot{\boldsymbol{q}}$ が連続となるような不等式拘束群を定義する ことである。この目標を達成するため， ロボットや環境を構成 する物体の表面上を連続に移動する点の組み合わせの集合を追 跡する方法を提案する.

拘束の不連続性は以下の場合に発生する。

（1）新たな拘束が突如として現れた場合

（2）既存の拘束が突如として消えた場合

最近点の不連続な移動はこれら二つの現象が同時刻に起こって いるものとみなすことができる.

これらの現象の発生を防ぎ，連続な速度による干渉回避運動 を生成するためには, 拘束する点の組み合わせは以下のような 条件を満たさなければならない。

（1）二つの物体が決して干渉しないことを保証するため, 少な くとも最近点は拘束しなければならない.

（2）最近点になる可能性がある点は最近点になる前からあらか じめ拘束しておかなければならない。

（3）最近点であった点は最近点でなくなった後も拘束し続けな ければならない。

問題を簡単にするため，多面体間の運動を多面体を構成する 面間の運動に分解して考える。ここでそれぞれの面は三角形に 分解されるものと仮定する†.

多面体 $\mathcal{O}_{1}, \mathcal{O}_{2}$ 間の連続な速度による運動は $\mathcal{O}_{1}$ を構成する それぞれの三角形が $\mathcal{O}_{2}$ を構成するそれぞれの三角形に対して 連続な速度で運動した場合に実現される。そこで二つの三角形

\footnotetext{
†以下で三角形の幾何要素とは一つの面, 三つの辺, 三つの頂点を指す.
}

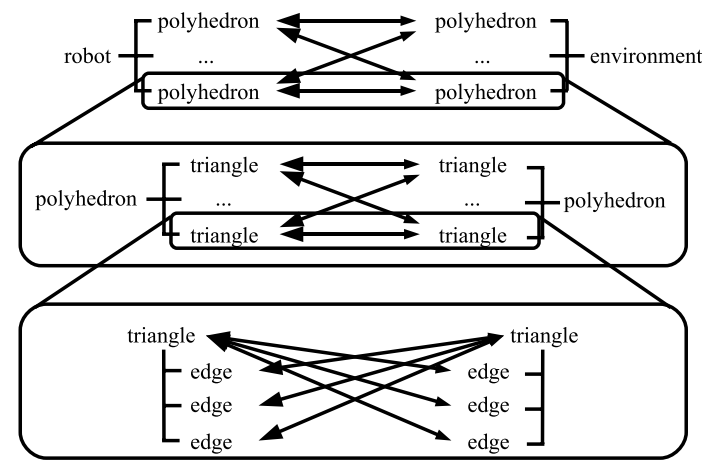

Fig. 5 Decomposition of interaction

$\mathcal{T}_{1}, \mathcal{T}_{2}$ 間の運動に着目する。 $\mathcal{T}_{1}$ と $\mathcal{T}_{2}$ の間の連続な速度によ る運動は $\mathcal{T}_{1}$ を構成する三つの辺それぞれが $\mathcal{T}_{2}$ に対して連続 な速度で運動し, かつ $\mathcal{T}_{2}$ を構成する三つの辺それぞれが $\mathcal{T}_{1} に$ 対して連続な速度で運動した場合に達成される。これにより多 面体間の運動は Fig. 5 に示すように辺と三角形間の運動に分解 され，辺と三角形間の連続な速度による運動を実現できればよ いことになる，同様にロボットや環境が複数の多面体で構成さ れている場合には，それぞれの多面体が他のすべての多面体に 対して連続な速度で運動することでロボットの連続な速度によ る運動が達成される。

\section{3 ボロノイ領域を用いた拘束生成}

次に辺と三角形が連続な速度で運動するために拘束しなけれ ばならない点の組み合わせについて検討を行う。拘束すべき点 の組み合わせは辺が三角形を構成するどの幾何要素のボロノイ 領域に含まれるかで以下のように場合分けされる。ボロノイ領 域は以下のように定義される.

Definition: 幾何要素 $X$ に対するボロノイ領域 $\mathcal{V} \mathcal{R}(X)$. $\mathcal{V R}(X)$ は $X$ への距離が他の幾何要素への距離よりも近い点 の集合である.

またボロノイ面は以下のように定義される.

Definition: 隣接する幾何要素 $X$ と $Y$ に対するボロノイ面 $\mathcal{V} \mathcal{P}(X, Y) . \mathcal{V P}(X, Y)$ は $\mathcal{V} \mathcal{R}(X) \cap \mathcal{V} \mathcal{R}(Y)$ を含む面である.

三角形は一つの面, 三つの辺, 三つの頂点から構成されるた め, 三角形の周囲は七つのボロノイ領域に分割される.

辺が $\mathcal{V} \mathcal{R}(\mathcal{F})$ に含まれる場合（Fig. 6 (左)）

最近点は辺と面とが平行になる状態を境に, 両端点間を不連続 に移動する。そこで二つの組み合わせ， $\left(\mathcal{V}_{1}, \mathcal{V}_{1}^{\prime}\right)$ と $\left(\mathcal{V}_{2}, \mathcal{V}_{2}^{\prime}\right)$ を 拘束する。 ここで $(a, b)$ は点 $a$ と点 $b$ の組み合わせを表し, $\mathcal{V}_{1}, \mathcal{V}_{2}$ は辺の両端点を, $\mathcal{V}_{i}^{\prime}(i=1,2)$ は $\mathcal{V}_{i}$ の三角形の法線に 沿った $\mathcal{F} へ の$ 投影点を表す。辺と三角形が平行な場合は辺上の 任意の点が最近点となりうるが，すでに両端点に対して拘束が 付与されているため，これに対する拘束は追加しない.

辺が $\mathcal{V} \mathcal{R}(\mathcal{E})$ に含まれる場合（Fig. 6 (中))

最近点は辺と $\mathcal{E}$ が平行になる状態を境に, 両端点間を不連続に 移動する。そこで二つの組み合わせ， $\left(\mathcal{V}_{1}, \mathcal{V}_{1}^{\prime}\right)$ と $\left(\mathcal{V}_{2}, \mathcal{V}_{2}^{\prime}\right)$ を拘 束する. ここで $\mathcal{V}_{i}^{\prime}(i=1,2)$ は $\mathcal{V}_{i}$ から $\mathcal{E}$ へ下ろした垂線の足 である。辺と $\mathcal{E} の$ 間の最近点は端点以外の場所にある場合があ る.そこで最近点の組も拘束に追加する。これにより三つの拘 束が生成される。 


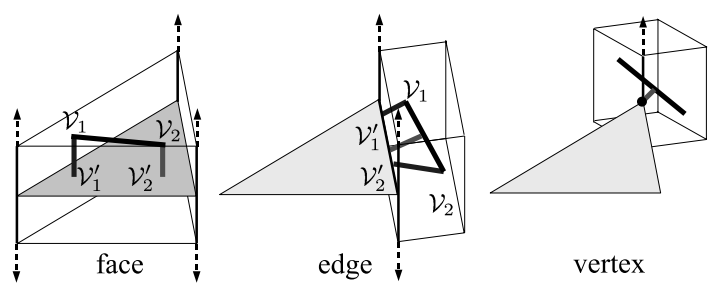

Fig. 6 Constraints generated between an edge and a triangle

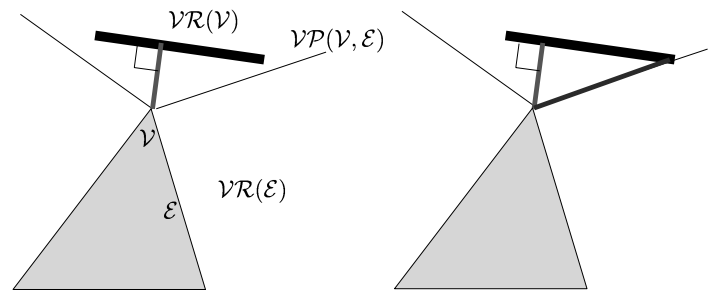

Fig. 7 Appearance/disappearance of a constraint

辺が $\mathcal{V R}(\mathcal{V})$ に含まれる場合（Fig. 6（右)）

最近点は辺上を連続に移動する. したがって頂点と辺間の最近 点のペアだけが拘束される。

ここまで辺がいずれかのボロノイ領域に完全に含まれる場合 について考えてきたが，実際には辺は隣接するボロノイ領域間を 移動したり, 複数のボロノイ領域にまたがって存在したりする。 そこでさらに辺をボロノイ面によって複数の線分に分割する。

分割するにあたり，辺が隣接するボロノイ領域を移動した場 合にも生成される拘束が連続であるかどうかを確認する，辺が $\mathcal{V R}(\mathcal{F})$ と $\mathcal{V R}(\mathcal{E})$ との間を移動する場合, 拘束の連続性は保た れる。 これは $\mathcal{V P}(\mathcal{F}, \mathcal{E})$ 上に存在する辺の分割点に対して, 二 つのボロノイ領域から同一の拘束が生成されるためである。こ れ以外の領域間の移動を行う場合, 拘束の出現または消滅が発生 する. 例を Fig. 7 に示す. 辺が $\mathcal{V R}(\mathcal{V})$ から $\mathcal{V R}(\mathcal{E})$ へと移動 する場合, 辺の端点が $\mathcal{V P}(\mathcal{V}, \mathcal{E})$ 上に来た瞬間に, その端点に 対して $\mathcal{V R}(\mathcal{E})$ から拘束が突如として生成される。逆に $\mathcal{V R}(\mathcal{E})$ から $\mathcal{V R}(\mathcal{V})$ 一と移動した場合， $\mathcal{V P}(\mathcal{V}, \mathcal{E})$ 上にあった拘束が 消滅する。 この不連続性は $\mathcal{V} \mathcal{R}(\mathcal{V})$ 内にある線分の両端点に対 しても拘束を追加することで解消されるため, 線分が $\mathcal{V R}(\mathcal{V})$ 内にあるときには合計三つの拘束を生成する.

この拘束の生成過程において，すべての線分の端点には拘束 が生成されるが，それらの端点は複数の線分によって共有され ているため重複が発生する。 また最近点が端点と一致した場合 にも重複が発生する。このため新たな拘束を追加する際には重 複をチェックする必要がある。

以上より拘束すべき点の組み合わせを決定するアルゴリズム は Algorithm 1-4 に示すように記述される。

Algorithm 1 は多面体 $\mathcal{O}_{1}, \mathcal{O}_{2}$ 間の運動を三角形間の運動に 分解して拘束生成を行う. TRIANGLES $(\mathcal{O})$ は $\mathcal{O}$ を構成する 三角形の集合を返す関数である.

Algorithm 2 は三角形 $\mathcal{T}_{1}, \mathcal{T}_{2}$ 間の運動を辺と三角形間の運 動に分解して拘束生成を行う。ここで $\operatorname{EDGES}(\mathcal{T})$ は $\mathcal{T}$ を構成 する辺の集合を返す関数である.

Algorithm 3 は辺を三角形のボロノイ領域を用いて複数の線 分に分割し，線分と三角形間の運動に関して拘束生成を行う。
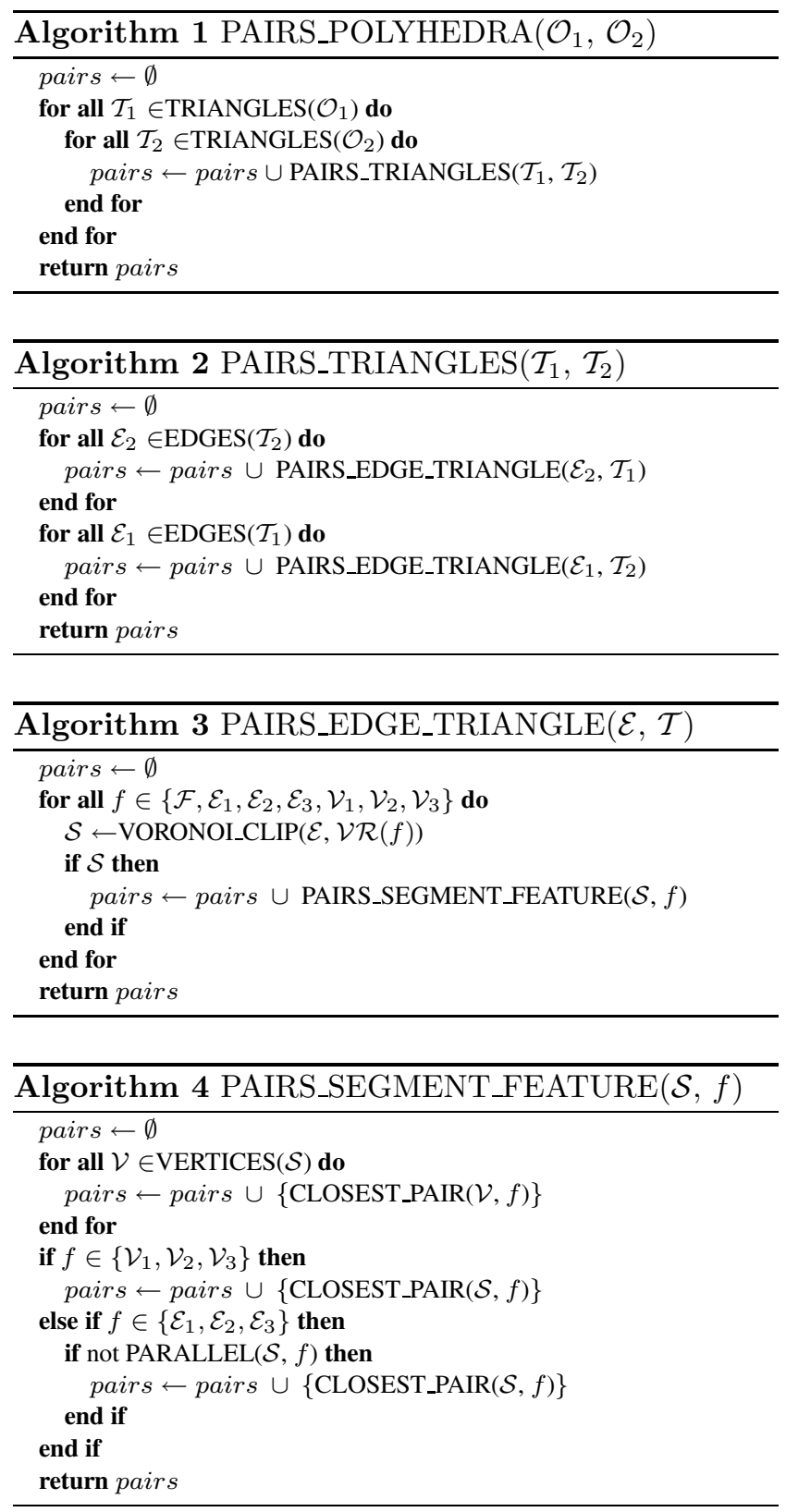

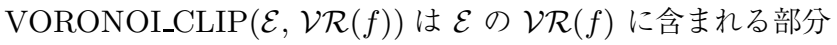
をクリッピングして取り出す関数である.

Algorthm 4 は実際に拘束する点の組み合わせを生成 する. $\operatorname{VERTICES}(\mathcal{S})$ は $\mathcal{S}$ の両端点の集合を返す関数, $\operatorname{PARALLEL}\left(\mathcal{S}_{1}, \mathcal{S}_{2}\right)$ は二つの線分が平行であるかどうかを 検查する関数, CLOSEST_PAIR $(A, B)$ は二つの幾何要素 $A$ と $B$ の間の最近点の組を返す関数である.

pairs を計算したあと，それぞれの組み合わせの点間の距離 が $d_{i}$ よりも小さかった場合に, velocity damperによる拘束が 適用される。

\section{4. 適用 例}

\section{1 単一物体間の障害物回避}

3.1 節の例に提案した手法を適用し，連続な速度による運動が 
$\mathrm{t}=0.0$

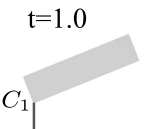

$\mathrm{t}=2.0$

$\mathrm{t}=3.0$

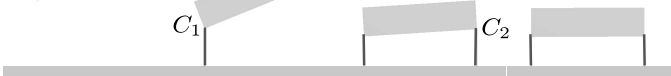

Fig. 8 Snapshots of interaction between a rectangle and the ground
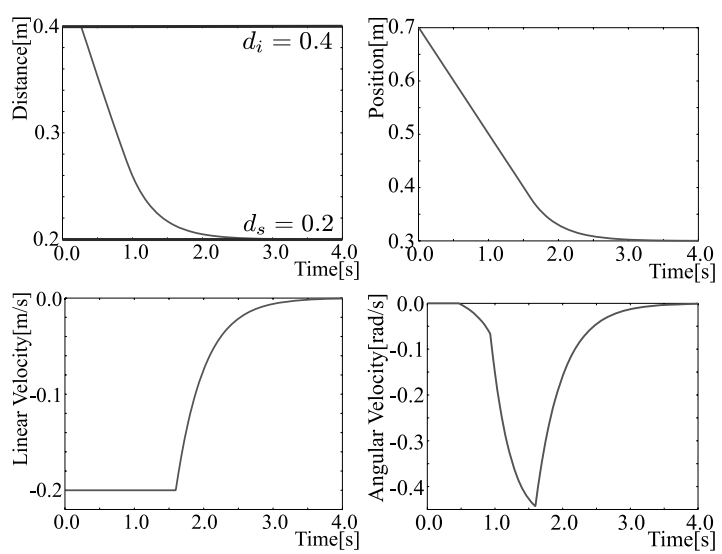

Fig. 9 Improved results of an example \#1
0

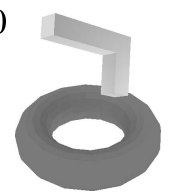

36

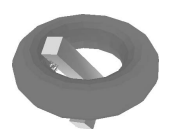

12

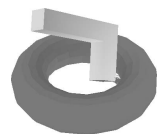

48

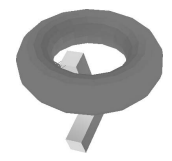

24

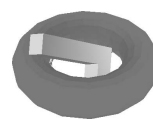

60

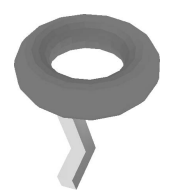

Fig. 10 Snapshots of an interaction between a concave shape and a torus

生成されることを確認したＦig. 8 に生成された運動のスナッ プショットを，Fig.9 に Fig. 4 に対応する結果を示す。物体間 の最短距離は $d_{s}$ へと収束し干渉は起きていない. $Y$ 軸方向の 並進速度および角速度は連続に変化していることが確認できる. この例では $C_{1}$ が influence zoneへ入った瞬間に最初の拘束が 生成され, $C_{2}$ が入ると二つ目の拘束が生成され, 以後二つの拘 束が適用される。

Fig. 10 は凹の物体や穴のある物体を含む例である.12の三 角形からなる L 字状の物体が 512 の三角形からなるトーラスの 中をすり抜けていく。このような形状の物体に対する干渉回避 運動を従来の手法で形状を近似することなしに生成するのは不 可能であった.

Fig. 11 左上に二つの物体間の最短距離, 右上に influence zone 内の三角形のペア数, 左下に生成された拘束の数, 右下に 計算時間を示す. 物体の形状が狭義に凸でない場合, 距離はこの ように連続で区分的に滑らかな関数となる. 最近点のペアは常 に拘束を受けているためこの場合も式 (5) が成り立ち, 二つの
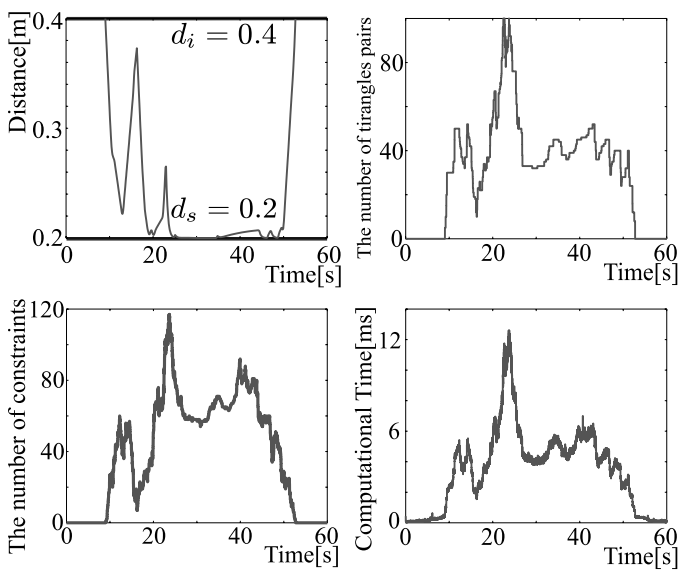

Fig. 11 Results of example \#2

物体間の距離は決して $d_{s}$ の值である 0.2 を下回らない. 物体が 狭義に凸の場合，二つの物体間に一つの拘束があれば十分である が, それ以外の形状の場合は複数の拘束が必要となる. この例で は最大で 117 の拘束が生成されている. 計算時間は Intel Core 2 Duo $2.13[\mathrm{GHz}]$ のプロセッサを搭載した PC 上で計測したも のであり，計算時間は三角形のペア数に比例することが分かる.

\section{2 ヒューマノイドロボットの干渉回避}

提案した手法をヒューマノイドロボット HRP-2 にも適用し た。計算に使用した幾何モデルは，CAD モデルを変換して得 られたものであり，全身で 20,858 個の三角形から構成される. ここでのタスクは全身を用いて左手を指定された位置へと移動 させることである，干渉を回避するための拘束の他に，以下の ような三つの拘束条件を追加する。（1）両脚で立った状態で夕 スクを遂行するため, 両足の相対位置関係を初期状態と同じ関 係に維持する。（2）静的なバランスを保つために, 重心の水平 位置を初期状態と同じ位置に維持する。 ただし, 初期状態にお いて重心は支持多角形上にあるものとする。（3）すべての関節 角度をそれぞれ可動範囲内に保つ。これらの条件の元で干渉な くタスクを遂行する運動は以下の最適化問題を解くことによっ て達成される。

$$
\min _{\dot{\boldsymbol{q}}} \quad\left\|\boldsymbol{J}_{\text {hand }} \dot{\boldsymbol{q}}-\underline{\dot{\boldsymbol{p}}}\right\|^{2}
$$

subject to

$$
\begin{aligned}
\left(\dot{\boldsymbol{q}} \mid \boldsymbol{J}_{\text {dist }_{j}}^{T} \boldsymbol{n}\right) \geq & -\xi \frac{d_{j}-d_{s}}{d_{i}-d_{s}}, \\
& \text { for } j \in\left\{1, \cdots, n_{c}\right\},
\end{aligned}
$$

$$
\begin{aligned}
& \boldsymbol{J}_{\text {feet }} \dot{\boldsymbol{q}}=\mathbf{0}, \\
& \boldsymbol{J}_{\text {com }} \dot{\boldsymbol{q}}=\mathbf{0} \text {, } \\
& v \max _{j}\left(q_{j}\right) \geq \dot{q}_{j} \geq v \min _{j}\left(q_{j}\right), \\
& \text { for } j \in\left\{1, \ldots, n_{\text {dof }}\right\} \text {. }
\end{aligned}
$$

ここで $\boldsymbol{J}_{\text {hand }}, \boldsymbol{J}_{\text {com }}, \boldsymbol{J}_{\text {feet }}, \boldsymbol{J}_{\text {dist }_{j}}$ はそれぞれハンドの位置 に関するヤコビ行列 $(3 \mathrm{DOF})$, 重心の水平位置に関するヤコビ行 列 (2DOF), 両足の相対位置·姿勢に関するヤコビ行列 $(6 \mathrm{DOF})$, $j$ 番目の点の組の間の距離に関するヤコビ行列（1DOF）であ 

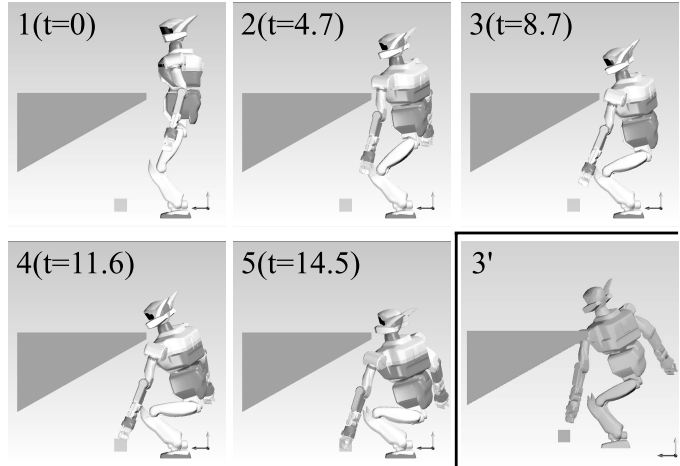

Fig. 12 Snapshots of "pick up an object under the table" motion

る. 不等式拘束（6b）は干渉を回避するための幾何拘束を定義 し, $n_{c}$ は拘束する点の組の数である。この例では $d_{i}, d_{s}, \xi$ は それぞれ $0.05[\mathrm{~m}], 0.03[\mathrm{~m}], 0.5[\mathrm{~m} / \mathrm{s}]$ とした。等式拘束 $(6 \mathrm{c})$ は両足間の相対位置・姿勢を維持するための運動学拘束を定義 する．等式拘束（6d）は重心の水平位置を維持するための動力 学拘束を定義する，不等式拘束（6e）は可動範囲に対応する運 動学拘束を定義する．ここで $n_{\text {dof }}$ は関節数である. 関節角度が 可動範囲限界からある範囲に近づくと限界に近づく速度を制限 するというものである。この制限值 $v \max _{j}, v \min _{j}$ は velocity damper によって以下のように計算される.

$$
\begin{gathered}
v \max _{j}\left(q_{j}\right)= \begin{cases}\xi \frac{\left(q_{j}^{+}-q_{j}\right)-q_{s}}{q_{i}-q_{s}} & \text { if } q_{j}^{+}-q_{j} \leq q_{i}, \\
v_{j}^{+} & \text {otherwise }\end{cases} \\
v \min _{j}\left(q_{j}\right)= \begin{cases}-\xi \frac{\left(q_{j}-q_{j}^{-}\right)-q_{s}}{q_{i}-q_{s}} & \text { if } q_{j}-q_{j}^{-} \leq q_{i}, \\
v_{j}^{-} & \text {otherwise }\end{cases}
\end{gathered}
$$

ここで $q_{j}^{+}, q_{j}^{-}$はそれぞれ $j$ 番目の関節の角度の最大值拉よび 最小值, $v_{j}^{+}, v_{j}^{-}$は角速度の最大值掞よび最小值である。この 例では $q_{i}, q_{s}, \quad \xi$ はそれぞれ $0.2[\mathrm{rad}], 0.02[\mathrm{rad}], 0.3[\mathrm{rad} / \mathrm{s}]$ とした.

Fig. 12 に生成された運動のスナップショットを示す. 1 コマ 目が初期状態である、ロボットの前にある台形のものが障害物, 足元にある箱が左手の目標位置を表している．2 コマ目で左腕 の上腕が障害物に近づいたために干渉回避のための拘束が有効 になる. 2 コマ目から 4 コマ目で左肩が障害物を避けているこ とが分かる. 5 コマ目では頭部が障害物に近づいたため, 右上 方を向くことで干渉を避けている，これらの運動でロボットは 全身を使って障害物を避けながら夕スクを遂行していることが 確認できる。 $3^{\prime}$ コマ目は不等式拘束（6b）なしに生成された動 作の 1 コマである. 左肩部分が障害物と干渉していることが分 かる.

Fig. 13 に生成された拘束の数（左）と計算時間（右）を示 す. 1 ステップ当たりの平均計算時間は㧍よそ $100[\mathrm{~ms}]$ であり, 生成された動作の総時間が $14[\mathrm{~s}]$ であるため, 時間刻みとして
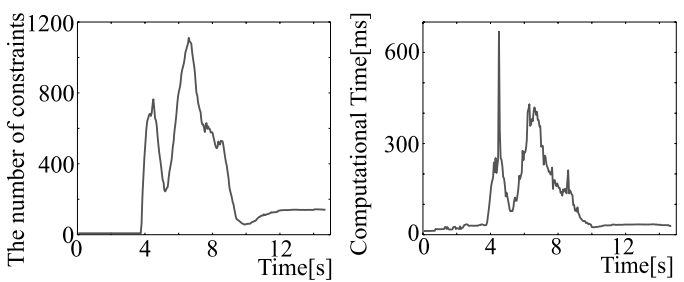

Fig. 13 Results of a picking up motion example

$50[\mathrm{~ms}]$ を選択した場合およそ $28[\mathrm{~s}]$ で動作生成が可能である.

\section{5. 結}

言

本稿では任意の多面体間の連続な速度による干渉回避運動を 生成する方法を提案した。

提案する手法により，ロボットや環境の幾何モデルが多面体 として与えられた場合に, それらの形状を一切近似することな しに速度連続な干渉回避運動生成に使用することが可能となる。

この速度の連続性は多面体間の運動をボロノイ空間によって 分割された線分と三角形の間の運動に分解し, それらの幾何要 素間にいくつかの拘束を生成することによって実現した，提案 した手法によって生成される拘束すべき点の組み合わせの集合 は, Faverjon らの方法だけでなく, 文献 [10]のような他の干渉 回避アルゴリズムにも適用可能である。

ヒューマノイドの場合, 動的な安定性が重要な問題であるが, 提案した手法ではZMP [17] に対する拘束を行っていないため, 動的安定性は保証されない. 重心の水平位置に対する拘束を与 えているため, 十分に小さな速度で動作を実行すれば安定と言 えるのみである. 動的安定性と動作の速度を両立させる方法を 検討中である.

謝 辞 提案手法の実装にはソフトウェアパッケージ CFSQP [18] を用いた. C-FSQP を開発した AEM Design に 感謝の意を表する.

\section{参 考 文 献}

[1] J. Kuffner, K. Nishiwaki, S. Kagami, M. Inaba and H. Inoue: "Motion Planning for Humanoid Robots Under Obstacle and Dynamic Balance Constraints," Proc. of International Conference on Robotics \& Automation, pp.692-698, 2001.

[2] Jr. J.J. Kuffner and S.M. LaValle: "RRT-Connect: An Efficient Approach to Single-Query Path Planning," Proc. IEEE International Conference on Robotics \& Automation, pp.995-1001, 2000 .

[ 3 ] S. Kagami, F. Kanehiro, Y. Tamiya, M. Inaba and H. Inoue: "AutoBalancer: An Online Dynamic Balance Compensation Scheme for Humanoid Robots," Proc. of the Fourth International Workshop on the Algorithmic Foundations on Robotics (WAFR'00), 2000.

[4] J. Kuffner, K. Nishiwaki, S. Kagami, Y. Kuniyoshi, M. Inaba and H. Inoue: "Self-Collision Detection and Prevention for $\mathrm{Hu}-$ manoid Robots," Proc. of International Conference on Robotics and Automation, pp.2265-2270, 2002.

[ 5 ] M. Mirtich: "VClip: Fast and robust polyhedral collision detection," ACM Transactions on Graphics, vol.17, no.3, pp.177208, 1998.

[6] K. Okada and M. Inaba: "A Hybrid Approach to Practical Self Collision Detection System of Humanoid Robot," Proc. of International Conference on Intelligent Robots and Systems, 
pp.3952-3957, 2006.

[7] B. Faverjon and P. Tournassoud: "A Local Based Approach for Path Planning of Manipulators With a High Number of Degrees of Freedom," Proc. of IEEE International Conference on Robotics and Automation, pp.1152-1159, 1987.

[8] C. Helguera and S. Zeghloul: "A Local-based Method for Manipulators Path Planning in Heavy Cluttered Environments," Proc. of International Conference on Robotics \& Automation, pp.3467-3472, 2000

[9] M. Schlemmer and G. Gruebel: "A Distance Function and its Gradient for Manipulator On-Line Obstacle Detection and Avoidance," Proc. of International Conference on Advanced Robotics, pp. 427-432, 1997.

[10] L. Sentis and O. Khatib: "A Whole-Body Control Framework for Humanoids Operating in Human Environments," Proc. of International Conference on Robotics and Automation, pp.2641-2648, 2006.

[11] F. Seto, K. Kosuge and Y. Hirata: "Self-collision Avoidance Motion Control for Human Robot Cooperation System using RoBE," Proc. of International Conference on Intelligent Robots and Systems, pp.50-55, 2005.

[12] H. Sugiura, M. Gienger, H. Janssen and C. Goerick: "RealTime Collision Avoidance with Whole Body Motion Control for Humanoid Robots," Proc. of International Conference on
Intelligent Robots and Systems, pp.2053-2058, 2007.

[13] E. Larsen, S. Gottschalk, M.C. Lin and D. Manocha: "Fast Proximity Queries with Swept Sphere Volumes," Proc. of International Conference on Robotics and Automation, pp.37193726,2000

[14] S.A. Ehmann and M.C. Lin: "Accelerated Proximity Queries Between Convex Polyhedra By Multi-Level Voronoi Marching," Proc. of International Conference on Intelligent Robots and Systems, pp.2101-2106, 2000.

[15] A. Escande, S. Miossec and A. Kheddar: "Continuous gradient proximity distance for humanoids free-collision optimizedpostures," Proc. of International Conference on Humanoid Robots, 2007.

[16] K. Kaneko, F. Kanehiro, S. Kajita, H. Hirukawa, T. Kawasaki, M. Hirata, K. Akachi and T. Isozumi: "Humanoid Robot HRP2," Proc. of IEEE International Conference on Robotics and Automation, pp.1083-1090, 2004.

[17] M. Vukobratović and B. Borovac: "Zero-moment point thirty five years of its life," International Journal of Humanoid Robotics, vol.1, no.1, pp.157-173, 2004.

[18] C. Lawrence, J.L. Zhou and A.L. Tits: User's Guide for CFSQP Version 2.5: A C Code for Solving (Large Scale) Constrained Nonlinear (Minimax) Optimization Problems, Generating Iterates Satisfying All Inequality Constraints, 1997.

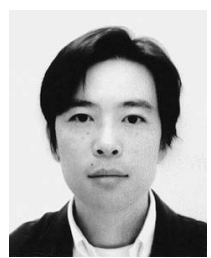

金広文男（Fumio Kanehiro）

1999 年東京大学大学院工学系研究科情報工学専攻 博士課程修了. 博士 (工学). 1998 年より日本学術 振興会特別研究員. 2000 年電子技術総合研究所入 所. 現在産業技術総合研究所知能システム研究部門 主任研究員. 2007 年より 1 年間 LAAS-CNRS 客 員研究員. ヒューマノイドロボットのシステム構成 法, 全身行動制御に興味がある. IEEE の会員.

(日本ロボット学会正会員)

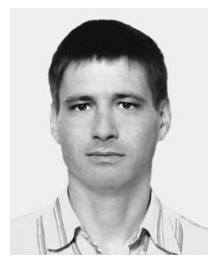

\section{Lamiraux Florent}

Florent Lamiraux graduated from the Ecole Polytechnique Paris, Paris, France, in 1993. He received the Ph.D. degree in computer science from the Institut National Polytechnique de Toulouse, Toulouse, France, in 1997 for his research on mobile robots. He was with Rice University, Houston, TX, for two years as a Research Associate. He is currently a Chargé de Recherche with LAAS-CNRS, Toulouse, France, and works on nonholonomic mobile robots.

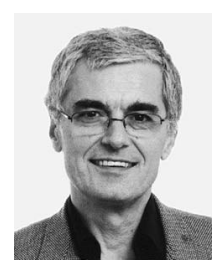

\section{Laumond Jean-Paul}

Jean-Paul Laumond is Directeur de Recherche at LAAS-CNRS in Toulouse, France. In Fall 1990 he was invited to be a senior scientist at Stanford University. He has been a member of the French Comité National de la Recherche Scientifique from 1991 to 1995 . He has been coordinator of two European Esprit projects -PROMotion and MOLOG- both dedicated to robot motion planning technology. In 2001 and 2002 he created and managed Kineo CAM, a spin-off company from LAAS-CNRS devoted to developing and marketing motion planning technology. He teaches robotics at ENSTA and Ecole Normale Supérieure in Paris. He has published more than 100 papers in international journals and conferences in computer science, automatic control, robotics and neurosciences. He is Fellow IEEE, IEEE RAS Distinguished Lecturer, and Editor of the IEEE Transactions on Robotics.

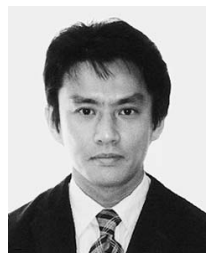

吉田英一（Eiichi Yoshida）

1996 年東京大学大学院工学系研究科博士課程修了, 同年通産省工業技術院機械技術研究所入所, 2001 年 4 月より独立行政法人産業技術総合研究所・知能シ ステム研究部門 主任研究員. 博士 (工学). 1990～ 1991 年スイスローザンヌ工科大学留学. 現在, 日 仏ロボット工学共同研究ラボラトリー (AIST/ISCNRS/ST2I Joint French-Japanese Robotics Laboratory, JRL) 共同ディレクター、ロボット作業・動作計画，モジュール型ロボット， 人間型ロボットの制御に興味をもつ。日本機械学会, 計測自動制御学 会, IEEEなどの会員.

（日本ロボット学会正会員）

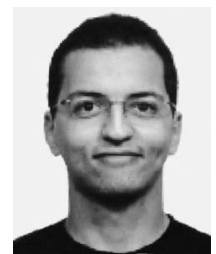

\section{Kanoun Oussama}

Oussama Kanoun graduated from Ecole des Mines de Paris with a major in Robotics. Obtained a Master degree from ENS Cachan in Mathematics for Computer Vision and Learning. Currently $\mathrm{PhD}$ student at LAAS-CNRS. 